\title{
ANALISIS SISTEM INFORMASI AKUNTANSI \\ PENGGAJIAN DALAM RANGKA EFEKTIVITAS \\ PENGENDALIAN INTERNAL PERUSAHAAN \\ (Studi Kasus pada CV. BAHARDIAN GALON)
}

\author{
Alfian Bahardiansyah, Riki Yulianto, Septika Puspitasari \\ alfiandian52@gmail.com \\ ryulianto451@gmail.com \\ septikapuspitasari55@gmail.com
}

\begin{abstract}
:
This study aims to analyze the payroll accounting information system that has been applied by $C V$. BAHARDIAN GALON and also to analyze the payroll accounting information system on the effectiveness of internal control. The type of research conducted is descriptive research, which focuses on payroll accounting information systems on $C V$. BAHARDIAN GALON and internal control system on CV. BAHARDIAN GALON. Data analysis in this study begins by analyzing related functions, supporting documents, accounting records used, network procedures and assessing the effectiveness of internal controls. The results of the study found evidence that the Accounting Department was still responsible for paying employee salaries and wages and was still responsible for supervising filling out employee attendance lists and making a recap of employee attendance lists so as to allow fraud. A healthy practice that is applied to support the effectiveness of internal control is that the basic salary of employees is paid by transferring the basic salary to each employee's account by the director and the salary slip is made in duplicate.
\end{abstract}

Keywords: Payroll Accounting Information System, Effectiveness of Internal Control

\begin{abstract}
Abstrak:
Penelitian ini bertujuan untuk menganalisa sistem informasi akuntansi penggajian yang telah diterapkan CV. BAHARDIAN GALON dan juga untuk menganalisa sistem informasi akuntansi penggajian pada efektivitas pengendalian internal. Jenis penelitian yang dilakukan adalah penelitian deskriptif, yang berfokus pada sistem informasi akuntansi
\end{abstract}


penggajian pada CV. BAHARDIAN GALON dan sistem pengendalian intern pada $\mathrm{CV}$. BAHARDIAN GALON. Analisis data dalam penelitian ini dimulai dengan menganalisa fungsi - fungsi yang terkait, dokumen pendukung, catatan akuntansi yang digunakan, jaringan prosedur dan menilai efektifitas pengendalian internal. Hasil penelitian menemukan bukti bahwa Bagian Akuntansi masih bertanggungjawab dalam pembayaran gaji dan upah karyawan serta masih bertanggungjawab melakukan pengawasan terhadap pengisian daftar hadir karyawan dan membuat rekap daftar hadir karyawan sehingga memungkinkan adanya penyelewengan. Praktek yang sehat yang diterapkan untuk mendukung efektifitas pengendalian intern adalah gaji pokok karyawan dibayarkan dengan mentransfer gaji pokok ke rekening masing - masing karyawan oleh direktur dan slip gaji dibuat rangkap dua.

Kata kunci: Sistem Informasi Akuntansi Penggajian, Efektivitas Pengendalian Intern 


\section{Pendahuluan}

Pada era globalisasi sekarang ini perusahaan dituntut untuk lebih efisien, efektif, dan ekonomis dalam menentukan besarnya biaya operasional perusahaan, karena faktor ini adalah salah satu yang terpenting untuk menghadapi persaingan yang semakin ketat dengan perusahaan lain. Dalam melaksanakan kegiatan operasi perusahaan diperlukan adanya manajemen perusahaan yang baik dengan ditunjang oleh personil yang perusahaan. Kinerja sumber daya manusia atau karyawan juga akan didukung dengan diterapkannya sistem informasi akuntansi pada perusahaan. "Sistem informasi akuntansi (SIA) adalah kumpulan sumber daya, seperti manusia dan peralatan yang diatur untuk mengubah data keuangan dan data lainnya menjadi informasi (Bodnar, 2003)

Untuk menjalankan kegiatannya dengan efektif dan efisien, sebuah perusahaan memerlukan suatu sistem pengolahan data informasi yang mendukungnya. Kebutuhan ini akan terpenuhi dengan adanya sistem informasi akuntansi. Sistem informasi akuntansi harus dirancang dan digunakan secara efektif, karena informasi akuntansi merupakan bagian yang paling penting dari seluruh informasi yang diperlukan oleh manajemen.

Sistem informas akuntansi dalam perusahaan dapat membantu pihak - pihak manajemen memperoleh informasi yang tepat dalam pengambilan keputusan untuk mencapai tujuan utama perusahaan termasuk dalam hal pemberian atau pembayaran kompensasi kepada karyawan yang berupa gaji dan upah. Biaya gaji dan upah yang jumlahnya cukup besar dapat meningkatkan risiko pengunaan gaji dan upah yang tidak semestinya.

Sistem pengendalian intern merupakan proses pemantauan yang memungkinkan manajemen mengetahui apakah tindakan yang dilakukan dan bagaimanakah tindakan koreksinya jika pelaksanaan tidak sesuai dengan yang telah ditetapkan semula. Suatu sistem pengendalian intern dikatakan memadai jika dengan diterapkannya sistem tersebut semua tujuan perusahaan dapat tercapai. Tujuan tersebut adalah pengamanan atau menjaga aktiva yang dimiliki, memeriksa ketelitian dan kebenaran data akuntansi, menjamin adanya efisiensi dalam operasional serta menjaga agar tidak terjadi penyimpangan dari kebijakan yang telah ditetapkan, dengan demikian dapat dilihat bahwa sistem pengendalian intern mempunyai peranan yang penting sekali bagi perusahaan.

CV. BAHARDIAN GALON adalah sebuah perusahaan yang bergerak dalam bidang jasa pelayanan pemeriksaan laboratorium klinik yang tentunya mempunyai Sumber Daya Manusia (SDM) cukup banyak dengan tingkat keahlian dan pendidikan yang tinggi. Dari berbagai transaksi pada perusahaan, kegiatan penggajian dan pengupahan mewakili transaksi yang penting 
dalam rangka pengendalian intern. Pengendalian atas gaji dan upah harus dilakukan dengan penuh ketelitian dan kecermatan agar transaksi tersebut tidak mengakibatkan kerugian yang harus diderita oleh perusahaan.

Berdasarkan latar belakang tersebut, tujuan yang ingin dicapai dalam penelitian ini adalah untuk menganalisa sistem informasi akuntansi penggajian yang telah diterapkan CV.BAHARDIAN dan untuk menganalisa sistem informasi akuntansi penggajian dan efektifitas pengendalian pada CV. BAHARDIAN GALON.

\section{Landasan Teori}

\section{Konsep Sistem Informasi Sistem}

Pada dasarnya kata sistem berasal dari kata yunani "sytema" yang berarti kesatuan, yakni keseluruhan dari bagian - bagian yang mempunyai hubungan satu sama lain. Untuk mendefinisikan sistem terdapat dua pendekatan, yaitu yang menekankan pada prosedurnya dan yang menekankan pada komponen atau elemennya. Pendekatan sistem yang menekankan pada prosedurnya mendefinisikan sistem sebagai suatu jaringan kerja dari prosedur-prosedur yang saling berhubungan, berkumpul bersama-sama untuk melakukan suatu kegiatan atau untuk menyelesaikan suatu sasaran yang tertentu. Prosedur adalah suatu uruturutan operasi klerikal (tulis menulis) biasanya melibatkan beberapa orang di dalam satu atau lebih departemen, yang diterapkan untuk menjamin penanganan yang seragam dari transaksitransaksi bisnis yang terjadi. Berbeda dengan sistem yang menekankan pada prosedurnya, sistem yang menekankan pada komponen atau elemennya mendefinisikan sistem sebagai kumpulan dari elemen-elemen yang berinteraksi untuk mencapai suatu tujuan tertentu. Pendekatan sistem yang merupakan kumpulan elemen- elemen atau komponen- komponen atau subsistem- subsistem merupakan definisi yang lebih luas. Pendekatan sistem yang menekankan pada komponen akan lebih di dalam mempelajari suatu sistem untuk tujuan analisis dan perancangan suatu sistem

\section{Menurut para ahli:}

Sistem menurut (Hall, 1956) adalah sekumpulan objek, yang mencakup hubungan diantara objek tersebut serta hubungan antara sifat yang mereka miliki. 
Menurut (Ackoff, 1971) sistem terdiri dari empat elemen yaitu, objek, atribut, hubungan internal dan lingkungan. Objek dapat berupa benda fisik, abstrak, ataupun keduanya sekaligus, tergantung kepada sifat sistem tersebut. Atribut, yang menentukan kualitas atau sifat kepemilikan sistem dan objeknya. Hubunganinternal, keterkaitan objek objek didalam sistem. Contohnya Nomor Induk Mahasiswa berhubungan dengan jenis buku yang dipinjam. Lingkungan, berkaitan dengan dimana sistem itu ditempatkan, contohnya yaitu sistem perpustakaan yang dibuat digunakan di Jurusan Teknik Elektro.

Syarat - syarat sesuatu disebut sistem menurut (H M Jogiyanto, 2005) yaitu, sistem dibentuk untuk menyelesaikan masalah, elemen sistem mempunyai perencanaan yang sudah ditetapkan, adanya hubungan antara elemen sistem, proses lebih diutamakan dari pada element sistem.

Menurut (Kadir, 2002) bahwa "Sistem adalah sekumpulan elemen yang saling terkait atau terpadu yang dimaksudkan untuk mencapai suatu tujuan”.

Menurut (Sutabri, 2012)bahwa "Sistem adalah suatu kumpulan atau himpunan dari suatu unsur, komponen, atau variabel yang terorganisasi, saling berinteraksi, saling tergantung satu sama lain dan terpadu”.

Menurut (Fathansyah, 2015) bahwa "Sistem adalah sebuah tatanan (keterpaduan) yang terdiri atas sejumlah komponen fungsional (dengan satuan fungsi dan tugas khusus) yang saling berhubungan dan secara bersama-sama bertujuan untuk memenuhi suatu proses tertentu".

Dari beberapa pengertian di atas penulis dapat menyimpulkan bahwa sistem merupakan sekumpulan elemen, himpunan dari suatu unsur, komponen fungsional yang saling berhubungan dan berinteraksi satu sama lain untuk mencapai tujuan yang diharapkan.

Pengertian dan definisi sistem yang telah dijelaskan diatas berbeda - beda namun kita dapat mengambil beberapa bersamaan umum, yaitu sistem harus memliki elemen, lingkungan dan hubungan antar keduannya. Sistem Informasi Inventarisasi Buku Perpustakaan Jurusan Teknik Elektro Universitas NegeriSemarang nantinya akan terdiri dari elemen - elemen yang saling berhubungan sehingga akan menghasilkan sistem yang baik untuk memberikan informasi yang dibutuhkan.

\section{Informasi}


Pengertian informasi menurut (McLeod Jr, 2001) adalah data yang telah diolah menjadi bentuk yang memiliki arti bagi si penerima dan bermanfaat bagi pengambilan keputusan saat ini atau mendatang.

Menurut (Sutabri, 2012) data yang diolah untuk menghasilkan informasi menggunakan suatu model proses tertentu. Data yang diolah melalui suatu model menjadi informasi, penerima kemudian menerima informasi tersebut, membuat suatu keputusan dan melakukan tindakan, yang berarti menghasilkan suatu tindakan yang lain yang akan membuat sejumlah data kembali. Data tersebut akan ditangkap sebagai input, diproses kembali lewat suatu model dan seterusnya membentuk suatu siklus.

\section{Sistem Informasi}

Sistem informasi adalah suatu sistem di dalam suatu organisasi yang mempertemukan kebutuhan pengolahan transaksi harian yang mendukung fungsi operasi organisasi yang bersifat manajerial dengan kegiatan strategi dari suatu organisasi untuk dapat menyediakan kepada pihak luar tertentu dengan laporan- laporan yang diperlukan (Sutarbi, 2005)

Sistem informasi yang dikemukakan oleh (Romney et al., 2000) dalam International Journal of Economics and Finance adalah sebuah sistem informasi adalah cara mengorganisir untuk mengumpulkan, mencatat, dan pengolahan data dan menyimpan, mengelola, mengendalikan, dan pelaporan informasi sehingga organisasi dapat mencapai tujuan dan sasaran.

Sistem informasi merupakan kesatuan elemen-elemen yang saling berinteraksi secara sistematis dan teratur untuk menciptakan dan membentuk aliran informasi yang akan mendukung pembuatan keputusan dan melakukan kontrol terhadap jalannya perusahaan (Watung \& Sinsuw, 2014).

Dari beberapa definisi tentang sistem informasi dapat disimpulkan bahwa sistem informasi adalah suatu sistem yang dirancang untuk menyediakan suatu informasi yang saling berinteraksi secara sistematis dan teratur.

Secara konseptual siklus pengembangan sebuah sistem informasi adalah sbb:

Analisis Sistem: menganalisis dan mendefinisikan masalah dan kemungkinan solusinya untuk sistem informasi dan proses organisasi.

Perancangan Sistem: merancang output, input, struktur file, program, prosedur, perangkat keras dan perangkat lunak yang diperlukan untuk mendukung sistem informasi 
Pembangunan dan Testing Sistem: membangun perangkat lunak yang diperlukan untuk mendukung sistem dan melakukan testing secara akurat. Melakukan instalasi dan testing terhadap perangkat keras dan mengoperasikan perangkat lunak

Implementasi Sistem: beralih dari sistem lama ke sistem baru, melakukan pelatihan dan panduan seperlunya.

Operasi dan Perawatan: mendukung operasi sistem informasi dan melakukan perubahan atau tambahan fasilitas.

Evaluasi Sistem: mengevaluasi sejauih mana sistem telah dibangun dan seberapa bagus sistem telah dioperasikan.Siklus tersebut berlangsung secara berulang-ulang. Siklus di atas merupakan model klasik dari pengembangan sistem informasi. Model-model baru, seperti prototyping, spiral, 4GT dan kombinasi dikembangkan dari model klasik di atas.

\section{Karakteristik Sistem Informasi}

Karakteristik sistem informasi menurut (Al Fatta, 2007) yaitu batasan sistem (boundary), lingkungan (environments), masukkan sistem (input), keluaran sistem (output), komponen (component), penghubung (interface), penyimpanan (storage).

Untuk mendukung keputusan yang akan dilakukan oleh manajemen, maka manajemen membutuhkan informasi yang berguna. (Hartono M Jogiyanto, 1999) menyebutkan karakteristik informasi yang baik antara lain :

1. Kepadatan informasi artinya penjelasan yang disampaikan tidak terlalu panjamg lebar langsung pada inti penyampaian informasi (to do point).

2. Luas informasi artinya penggunaan informasi harus menyeluruh namun tidak terlalu lebar untuk penggunaan informasi.

3. Frekuensi informasi artinya jumlah penggunaan data dalam sistem informasiyang digunakan selalu dijaga sehingga tidak terlalu banyak informasi yang sama atau banyak Jadwal informasi artinya informasi harus selalu diperbaharui sehingga bersifat uptodate.

4. Waktu informasi artinya penjelasan kapan informasi itu dikeluarkan harus jelas.

5. Akses informasi artinya untuk mendapatkan informasi dapat didapat dengan mudah dan cepat.

6. Sumber informasi artinya informasi berasal dari pihak yang 
bisa dipertanggungjawabkan.

Penjelasan diatas merupakan dasar untuk pembuatan Sistem Inventarisasi Buku Perpustakaan Jurusan Teknik Elektro Universitas Negeri Semarang yang memiliki kriteria informasi baik dan sistem informasi yang baik. Sistem merupakan suatu bentuk integrasi antara satu komponen dengan komponen lain karena sistem memiliki sasaran yangn berbeda untuk setiap kasus yang terjadi di dalam sistem tersebut. Oleh karena itu sistem dapat diklasifikasikan dari beberapa sudut pandangan :

1. Sistem abstrak dan sistem fisik

- Sistem abstrakyaitu sistem yang berupa pemikiran atau ide-ide yang tidak tampak secara fisik. Contohnya sistem teologia, yaitu satu sistem yang berupa pemikiran tentang hubungan antara manusia dengan Tuhan.

- $\quad$ Sistem Fisik yaitu sistem yang ada secara fisik, contohnya sistem komputer, sistem produksi, sistem penjualan, sistem administrasi personalia, dsb.

2. Sistem alamiah dan sistem buatan manusia

- Sistem alamiahyaitu sistem yang terjadi melalui proses alam, tidak dibuat oleh manusia, contohnya sistem pemutaran bumi, terjadinya siang malam, pergantian musim.

- Sistem buatan manusia yaitu sistem yang melibatkan hubungan manusia dengan mesin, yang disebut denga Human machine Sistem. Contohnya sistem informasi berbasis komputer, karena menyangkut penggunaan komputer yang berinteraksi dengan manusia.

3. Sistem deterministik dan sistem probabilistik

- Sistem deterministik yaitu sistem yang beroperasi dengan tingkah laku yang dapat diprediksi. Contohnya sistem pemprograman dalam komputer, karena berdasarkan program2 komputer yang dijalankan.

- $\quad$ Sistem probabilistik yaitu sistem yang kondisi masa depannya tidak dapat diprediksi karena mengandung unsur probabilitas. Contohnya sistem pemilu, sistem pemerintahan.

4. Sistem terbuka dan sistem tertutup

Sistem terbukayaitu sistem yang berhubuingan dan dipengaruhi oleh lingkungan luarnya yang menerima masukan dan menghasilkan keluaran untuk sub sistem lainnya. Contohnya sistem perdagangan.

- $\quad$ Sistem tertutupyaitu sistem yang tidak berhubungan dan tidak dipengaruhi oleh lingkungan luarnya. Sistem ini bekerja secara otomatis tanpa ada campur tangan dari pihak luar. Contohnya sistem robotic, sistem arloji, ATM sistem.

Siklus hidup sistem yaitu proses evolusioner yang diikuti dalam penerapan sistem atau sub sistem informasi berbasis komputer. Siklus hidup sistem terdiri dari serangkaian tugas yang 
mengikuti langkah-langkah pendekatan sistem, karena tugas-tugas tersebut mengikuti pola yang teratur dan dilakukan secara topdown. Siklus hidup sistem sering disebut sebagai pendekatan air terjun (waterfall approach) bagi pembangunan dan pengembangan sistem. Pembangunan sistem hanyalah salah satu dari serangkaian dari daur hidup suatu sistem, meskipun demikian proses ini merupakan aspek yang sangat penting.

Fase/tahapan dari daur hidup suatu sistem :

a. Mengenali adanya kebutuhan

Sebelum segala sesuatunya terjadi, timbul suatu kebutuhan atau problema yang harus dapat dikenali sabagaimana adanya. Kebutuhan dapat terjadi sebagai hasil perkembangan organisasi. Volume kebutuhan itu meningkat melebihi kapasitas dari sistem yang ada. Semua kebutuhan ini harus dapat didefinisikan dengan jelas. Tanpa adanya kejelasan dari kebutuhan yang ada, pembangunan sistem akan kehilangan arah dan efektivitasnya.

\section{b. Pembangunan sistem}

Suatu proses atau serangkaian prosedur yang harus diikuti guna menganalisis kebutuhan yang timbul dan membangun sebuah sistem untuk memenuhi kebutuhan tersebut.

\section{c. Pemasangan sistem}

Setelah tahap pembangunan selesai, sistem kemudian akan dioperasikan. Pemasangan sistem merupakan tahap yang penting dalam daur hidup sistem, dimana peralihan dari tahap pembangunan menuju tahap operasional adalah pemasangan sistem yang merupakan langkah akhir dari suatu pembangunan sistem.

\section{d. Pengoperasian sistem}

Program - program komputer dan prosedur - prosedur pengoperasian yang membentuk suatu sistem informasi semuanya bersifat statis, sedangkan organisasi yang ditunjang oleh sistem informasi selalu mengalami perubahan karena pertumbuhan kegiatan, perubahan peraturan dan kebikjaksanaan ataupun kemajuan teknologi. Untuk mengatasi perubahanperubahan tersebut, sistem harus diperbaiki atau diperbaharui.

\section{e. Sistem menjadi usang}

Kadang - kadang perubahan yang terjadi begitu drastis sehingga tidak dapat diatasi hanya 
dengan melakukan perbaikan pada sistem yang sedang berjalan. Tiba saat dimana secara ekonomis dan teknis, sistem yang ada sudah tidak layak lagi untuk dioperasikan dan sistem yang baru perlu dibangun untuk menggantikannya.

\section{Arti Penting Pengembangan Sistem}

(Rachmad Gesah Mukti prabowo, 2015) Pengembangan sistem (systems development) merupakan menyusun suatu sistem yang baru untuk menggantikan sistem yang lama secara keseluruhan atau memperbaikis istem yang telah ada. Sistem yang lama perlu diperbaiki atau diganti disebabkan karena beberapa hal, yaitu sebagai berikut ini:

1. Adanya permasalahan-permasalahan (problems) yang timbul di sistem yang lama.

2. Ketidakberesan dalam sistem yang lama menyebabkan sistem yang lama tidak dapat beroperasi sesuai dengan yang diharapkan.

3. Kecurangan-kecurangan disengaja yang menyebabkan tidak amannya harta kekayaan perusahaan dan kebenaran dari data menjadi kurang terjamin.

4. Kesalahan-kesalahan yang tidak disengaja yang juga dapat menyebabkan kebenaran dari data kurang terjamin.

5. Tidak efisiennya operasi.

6. Tidak ditaatinya kebijaksanaan manajemen yang telah ditetapkan.

\section{Pengertian Sistem Informasi Akuntansi}

Pengertian Sistem Informasi Akuntansi (SIA) adalah sistem yang dirancang untuk mengumpulkan dan menampilkan informasi akuntansi sehingga akuntan dan eksekutif perusahaan dapat membuat keputusan yang tepat.

Menurut (bodnar, george h., 2003) : "Sistem informasi akuntansi (SIA) adalah kumpulan sumber daya, seperti manusia dan peralatan yang diatur untuk mengubah data keuangan dan data lainnya menjadi informasi”. Informasi ini kemudian dikomunikasikan kepada berbagai pihak pengambil keputusan. (Mulyadi, 2001b) menyatakan bahwa "sistem informasi akuntansi adalah organisasi formulir, catatan, dan pelaporan yang dikoordinasikan sedemikian rupa untuk menyediakan informasi keuangan yang dibutuhkan oleh manajemen 
guna memudahkan pengelolaan data perusahaan". Sistem informasi akuntansi merupakan suatu prosedur yang digunakan dalam menyampaikan data kegiatan terutama yang berhubungan dengan informasi keuangan kepada pihak yang berkepentingan. Adapun unsur dari sistem akuntansi adalah formulir, catatan, peralatan yang digunakan untuk mengolah data dalam menghasilkan informasi keuangan yang diperlukan oleh manajemen (Hidayat, Rahayu, 2013) Sedangkan, menurut (Widjajanto, 2001), Pengertian Sistem Informasi Akuntansi atau SIA adalah susunan formulir, catatan, dan peralatan. Dari sini dapat disimpulkan, bahwa Sistem Informasi Akuntansi adalah suatu sistem yang terdiri dari berbagai formulir, catatan dan laporan yang telah disusun dan menghasilkan suatu informasi keuangan yang dibutuhkan oleh perusahaan

\section{Sistem Informasi Akuntansi Penggajian}

Menurut (Mulyadi, 2001c)“sistem akuntansi penggajian dirancang untuk menangani transaksi perhitungan gaji karyawan dan pembayarannya". (Mulyadi, 2001a)"sistem informasi akuntansi penggajian digunakan untuk melaksanakan perhitungan, pembayaran, dan pencatatan gaji bagi karyawan yang dibayar tetap bulanan

(Mulyadi, 2001b)memberikan definisi gaji adalah sebagai berikut: gaji merupakan pembayaran atas penyerahan jasa yang dilakukan oleh karyawan yang mempunyai jenjang jabatan manajer, umumnya gaji diberikan secara tetap perbulan. Berdasarkan beberapa pendapat tersebut, pada dasarnya sistem informasi akuntansi penggajian adalah sistem informasi akuntansi yang digunakan untuk menangani atau melaporkan transaksi - transaksi dan memberikan informasi terkait dengan penggajian karyawan.

\section{Efektifitas}

Efektivitas kadang dijadikan sebagai tolak ukur atas suatu keberhasilan perusahaan. Apabila kegiatan berjalan dengan efektif maka suatu perusahaan dapat dikatakan sudah berhasil. Efektivitas perusahaan adalah kemampuan suatu perusahaan untuk mencapai tujuan yang diinginkan dengan memanfaatkan sumber daya yang dimilikinya (Danke, 2012) Semakin sedikit sumber daya yang dipakai untuk menghasilkan sesuatu yang lebih banyak dapat dikatakan perusahaan sudah mencapai efektivitasnya. 


\section{Pengendalian Internal dalam sistem informasi akuntansi penggajian}

Pengendalian internal adalah suatu aktivitas berupa prosedur-prosedur yang harus dilakukan untuk memberi keyakinan yang layak bahwa suatu kegiatan yang dilakukan tidak menyimpang dari yang seharusnya. Pengendalian internal saat ini makin dibutuhkan oleh perusahaan yang ingin menjalankan kegiatannya secara efektif dan efisien Menurut (Saraswaati, Darminto, 2014)pada dasarnya sistem pengendalian intern adalah kesatuan dari struktur organisasi serta alat - alat yang mendukung untuk melakukan pengawasan terhadap kegiatan - kegiatan yang berhubungan dengan penggunaan harta milik perusahaan serta untuk meminimalkan terjadinya kesalahan, kecurangan dan penyelewengan yang terjadi pada perusahaan agar kegiatan operasional perusahaan dapat berjalan dengan lancar untuk mendukung tercapainya tujuan utama perusahaan.

Tujuan pengendalian internal seperti yang dikemukan oleh (Elder, Randal J., Mark S.B., 2009) yang diterjemahkan oleh Amir Abadi Yusuf adalah:

1. Efektivitas dan efisiensi operasi.

Pengendalian internal bertujuaan untuk mencapai efektivitas dan efisiensi dalam kegiatan operasi perusahaan, hal ini termasuk pelaksanaan kegiatan, pencapaian hasil, dan usaha perlindungan terhadap kerugian. Pengendalian internal dibutuhkan atas sumber daya yang dimiliki perusahaan, agar sumber daya ini tidak disalahgunakan oleh orang-orang atau pihak yang tidak berkepentingan dan tidak berwenang. Manajemen harus memiliki data dan informasi yang akurat agar pengambilan keputusan dapat dilakukan secara cepat dan tepat.

2. Realibilitas

atas Pelaporan Keuangan Manajemen bertanggung jawab atas pelaporan keuangan yang diterbitkan oleh perusahaan. Pengendalian internal bertujuan agar pelaporan keuangan yang diterbitkan dapat dipercaya, hal ini termasuk pencegahan atas kecurangan pada pelaporan keuangan. Kecurangan atas pelaporan keuangan biasanya disebabkan karena permintaan dari pihak eksternal. Pengendalian internal bertujuan agar pelaporan keuangan yang ada dapat sesuai dengan prinsip akuntansi yang berlaku umum. 
3. Kepatuhan terhadap Hukum dan Peraturan Pengendalian internal bertujuan untuk memastikan bahwa segala peraturan dan ketetapan yang sudah dibuat oleh perusahaan sudah dipatuhi dengan baik dan benar oleh para karyawannya. Pengendalian internal dapat mengendalikan kegiatan perusahaan agar dapat sesuai dengan peraturan dan hukum yang berlaku.

\section{Fungsi Sistem Informasi Akuntansi}

Sistem keuangan yang menyediakan informasi memiliki beberapa fungsi dalam keberlangsungan usaha. Berikut beberapa fungsi dari Sistem Informasi Akuntansi adalah:

Mengumpulkan semua data kegiatan bisnis perusahaan dan menyimpan data tersebut secara efektif dan efisien. Selain itu, SIA juga dapat mencatat semua sumber daya yang berpengaruh terhadap usaha tersebut dan semua pihak yang terkait. Dengan fungsi ini, tidak akan ada suatu hal dalam perusahaan yang tidak tercatat.

Mengambil data yang diperlukan dari berbagai sumber dokumen yang berkaitan dengan aktivitas bisnis. Data yang sudah tersimpan akan lebih mudah diambil karena setiap detail dari data sudah terekam dengan SIA.

Membuat dan mencatat data transaksi dengan benar ke dalam jurnal-jurnal yang diperlukan dalam proses akuntansi sesuai dengan urutan dan tanggal terjadinya transaksi. Pencatatan ini bertujuan untuk mempermudah pihak-pihak yang membutuhkan dalam pengecekan semua transaksi sehingga jika terjadi suatu kesalahan dapat dikoreksi dengan mudah dan dapat diketahui penyebabnya dengan cepat.

Mengubah sekumpulan data menjadi informasi keuangan yang dibutuhkan perusahaan. Informasi ini berbentuk laporan keuangan baik secara manual maupun secara online yang diperlukan oleh semua pihak.

Sebagai suatu sistem pengendali keuangan, agar tidak terjadi suatu kecurangan. Dengan sistem ini, keuangan perusahaan dapat dilacak dengan pasti karena sistem pertanggungjawaban yang detail. Fungsi ini dapat menjaga aset perusahaan dan mengurangi risiko untuk penggelapan aset oleh semua pihak terkait.

Meskipun informasi yang terkandung dalam sistem bervariasi antara industri dan ukuran bisnis, SIA mencakup data yang berkaitan dengan: 
- Pendapatan

- Pengeluaran

- Data pelanggan

- Data karyawan

- Informasi pajak

- Invoice

Data, Laporan, dan Fitur dalam Sistem Informasi Akuntansi

Sistem Akuntansi Informasi menyediakan dua tipe dasar pencatatan akuntansi yaitu Jurnal dan Buku Besar Pembantu.

\section{Jurnal}

Ada dua jenis jurnal yaitu jurnal umum dan jurnal khusus.

Semua entri jurnal dapat dicatat di jurnal umum, yang mengharuskan setiap debit dan kredit dimasukkan secara manual.

Jurnal khusus digunakan untuk mencatat jenis transaksi serupa. Sistem informasi akuntansi biasanya memiliki empat jurnal khusus:

Jurnal penjualan untuk mencatat penjualan kredit

Jurnal penerimaan kas untuk mencatat semua transaksi yang memiliki debit menjadi kas

Jurnal pembelian untuk mencatat semua pembelian yang dilakukan secara kredit (kredit ke hutang dagang)

Jurnal pengeluaran kas untuk mencatat semua transaksi pengkreditan kas

\section{Buku Besar Pembantu (Subsidiary Ledger)}

Fitur umum kedua dari sistem informasi akuntansi adalah penggunaan buku besar pembantu.

Buku besar pembantu adalah daftar semua transaksi yang membentuk akun buku besar umum. 
Dua dari buku besar pembantu yang paling umum adalah:

Buku besar piutang dagang, di mana transaksi dengan setiap pelanggan individu dicatat

Buku besar hutang dagang, dimana transaksi dengan vendor individu dicatat

Jurnal dan buku besar pembantu ini adalah komponen untuk banyak laporan lainnya, contohnya:

- Laporan piutang

- Penyusutan aset tetap

- Neraca Saldo

- Buku Besar

- Inventaris stok barang

- Dll

Dengan beberapa informasi tambahan yang ditangkap di tempat lain dalam sistem, informasi penting seperti pelanggan dan profitabilitas produk, hutang dagang dan umur piutang, dan proyeksi arus kas, dan pembukuan menjadi lebih mudah untuk dilakukan.

Selain itu, sistem pembukuan dapat menghasilkan laporan keuangan seperti laporan neraca, laporan laba rugi, laporan arus kas atau cash flow, serta laporan pengembalian pajak.

Informasi akuntansi dapat diurutkan berdasarkan berbagai kriteria, memberikan wawasan penting bagi manajemen tentang operasi bisnis, sehingga dapat mengambil keputusan dengan tepat.

\section{Bagian SIA adalah}

People : Mengoperasikan sistem dan melakukan berbagai fungsi.

Procedure : Mengumpulkan, memproses dan menyimpan data yang berhubungan dengan aktivitas organisasi.

Data : Kegiatan atau proses bisnis.

Software : Memproses data yang ada di organisasi. 
Infrastruktur Informasi Teknologi : komputer dan peralatan lainnya.

Keandalan Sistem

Menurut American Institute of CPA (AICPA) dan Canadian Institute of Chartered Accountants (CICA), terdapat lima prinsip dasar yang penting bagi keandalan sistem ini, yaitu :

- Keamanan - Akses ke sistem dan datanya dikontrol dan dibatasi hanya untuk yang berwenang.

- Kerahasiaan - Perlindungan informasi sensitif dari pengungkapan yang tidak sah.

- Privasi - Pengumpulan, penggunaan, dan pengungkapan informasi pribadi tentang pelanggan dilakukan dengan cara yang tepat dan privat.

- Memproses integritas - Pemrosesan data yang akurat, lengkap, dan tepat waktu dilakukan dengan otorisasi yang tepat.

- Ketersediaan - Sistem ini tersedia untuk memenuhi kewajiban operasional sesuai kontrak.

Jika perusahaan menerapkan SIA adalah dengan baik, diharapkan semua laporan dapat disajikan tepat waktu. Jadi semua pihak internal maupun eksternal dapat mengambil keputusan dengan baik mengenai perkembangan perusahaan. Penggunaan SIA yang efektif akan membantu perkembangan perusahaan dalam jangka waktu yang panjang. Untuk mendukung sebuah usaha yang memiliki sebuah SIA yang baik tentunya butuh sistem pencatatan dan pelaporan yang baik pula.

\section{Metode Penelitian}

Jenis penelitian yang digunakan dalam penelitian ini adalah penelitian deskriptif dengan metode analisis data yaitu analisis data kualitatif. Menurut (Mardalis, 2010) penelitian deskriptif, bertujuan untuk mendeskripkan apa - apa yang saat ini berlaku. Di 
dalamnya terdapat upaya mendeskripsikan, mencatat, analisis dan mengintreprestasikan kondisi - kondisi yang sekarang ini terjadi atau ada. Dengan kata lain penelitian deskriptif bertujuan untuk memperoleh informasi - informasi mengenai keadaan saat ini, dan melihat kaitan antara variabel - variabel yang ada. Penelitian ini tidak menguji hipotesa atau tidak menggunakan hipotesa, melainkan hanya mendeskripsikan informasi apa adanya sesuai dengan variabel - variabel yang diteliti

Berdasarkan pendapat tersebut, pada dasarnya penelitian deskriptif dilakukan untuk mengamati dan mengetahui suatu objek penelitian dengan lebih jelas dengan tujuan agar dapat mendeskripkan objek penelitian sesuai dengan fakta yang ada dan dapat membandingkan antara teori dan praktik yang terjadi di lapangan, sehingga dapat ditemukan solusi untuk permasalahan yang timbul pada objek penelitian. Penelitian ini berfokus pada sistem informasi akuntansi penggajian dan sistem pengendalian intern pada $\mathrm{CV}$. BAHARDIAN GALON.

Metode pengumpulan data yang digunakan adalah wawancara, dokumentasi dan observasi.

Dalam metode ini dilakukan dengan cara tanya jawab secara langsung mengenai sistem informasi akuntansi penggajian karyawan kepada bagian keuangan, bagian penggajian dan bagian administrasi. Penulis juga melakukan pengamatan secara langsung terhadap sistem pengendalian intern penggajian karyawan pada perusahaan. Data yang diperoleh misalnya dokumen pernyataan gaji, kartu absensi, formulir-formulir dalam prosedur penggajiannya, daftar gaji dan rekap daftar gaji. Dalam metode ini penulis membuat catatan kecil, membaca laporan akhir tahun sebelumnya yang ada pada perusahaan yang berguna untuk menyusun gambaran umum perusahaan. Penerapan sistem informasi akuntansi penggajian yang belum efektif akan diberikan alternatif pemecahan masalah untuk membantu perusahaan menerapkan sistem akuntansi penggajian dan pengupahan yang efektif. Analisis data dalam penelitian ini dimulai dengan menganalisa sistem informasi akuntansi penggajian yang telah diterapkan perusahaan dengan cara melakukan analisis terhadap fungsi - fungsi yang terkait, analisis terhadap dokumen yang digunakan, analisis terhadap catatan akuntansi yang digunakan dan analisis terhadap jaringan

prosedur yang membentuk sistem informasi akuntansi penggajian pada perusahaan. Menganalisis dan menilai efektifitas pengendalian internal yang dimiliki oleh perusahaan yang berkaitan dengan sistem akuntansi penggajian yang terdiri dari analisis struktur 
organisasi, analisis sistem otorisasi dan prosedur pencatatan, analisis praktik yang sehat dan karyawan yang sesuai dengan mutunya.

\section{Pembahasan}

\section{Analisis Sistem Informasi Akuntansi Penggajian pada PT. Populer Sarana Medika}

Penggajian bagi para karyawan di PT. Populer Sarana Medika didasarkan pada kemampuan suatu lembaga sebagai standar gaji pokoknya, kemudian ditambah tunjangan jabatan, tunjangan transport, uang makan, dan premi hadir, selanjutnya dikurangi dengan potongan gaji seperti utang gaji karyawan. Ketentuan besarnya tunjangan yang diberikan kepada karyawan ini diperhitungkan berdasarkan jabatan dan masa kerja karyawan yang bersangkutan. PT. Populer Sarana Medika memberikan tunjangan atau jaminan sosial kepada karyawannya dalam rangka usaha pemeliharaan tenaga kerja.

Penerapan atau pelaksanaan penggajian karyawan pada PT. Populer Sarana Medika sudah cukup baik dan sudah sesuai dengan teori yang ada. Besar gaji pokok yang diterima masing - masing karyawan ditentukan oleh pihak manajemen sesuai jabatan masing - masing karyawan. Namun penerapan atau pelaksanaan penggajian di PT. Populer Sarana Medika masih terdapat kelemahan diantaranya tidak ada uang transport bagi karyawan yang tinggal di mess. Pihak manajemen mengasumsikan bahwa karyawan yang tinggal di mess tidak membutuhkan uang transport karena lokasi mess berada satu tempat dengan perusahaan.

\section{Analisis Fungsi - Fungsi yang Terkait dalam Sistem Informasi Akuntansi Penggajian pada PT. Populer Sarana Medika}

Fungsi - fungsi yang terkait dalam sistem informasi akuntansi penggajian pada PT. Populer Sarana Medika adalah :

\section{a. Bagian Akuntansi}

Bagian akuntansi bertugas untuk membuat rekap daftar hadir karyawan, daftar gaji karyawan, slip gaji, lembar penerimaan gaji, bukti kas keluar, dan 
bertanggung jawab mencatat transaksi - transaksi penggajian pada jurnal umum dan buku besar.

\section{b. Direktur}

Direktur berwenang dalam proses pembayaran gaji pokok karyawan. Melakukan transfer gaji pokok, tunjangan jabatan, tunjangan transport, uang makan, dan premi hadir ke rekening masing - masing karyawan dan mentransfer biaya pembayaran pendapatan per bulan ke rekening Bagian Akuntansi melalui E-bankin ( Electronic Banking ).

Fungsi-fungsi yang terkait dengan sistem informasi akuntansi penggajian pada PT. Populer Sarana Medika kurang baik dan belum sesuai dengan teori yang ada. Alternatif - alternatif untuk mengurangi kelemahan pada fungsi - fungsi yang terkait dalam sistem informasi akuntansi penggajian antara lain : Terdapat bagian khusus seperti fungsi pembuat daftar gaji (bagian akuntansi) yang bertanggung jawab untuk membuat daftar gaji yang berisi gaji pokok serta tunjangan-tunjangan yang diberikan kepada karyawan dan potongan-potongan yang menjadi beban

karyawan setiap bulannya. Daftar gaji tersebut dikelola oleh fungsi pembuat daftar gaji guna pembuatan daftar gaji yang akan diajukan ke kasir, untuk pembayaran gaji pegawai. Selain itu, harus ada fungsi pencatat waktu (bagian personalia) yang bertanggungjawab untuk membuat rekap daftar hadir karyawan dan menyelenggarakan waktu hadir bagi semua karyawan PT. Populer Sarana Medika. Sistem pengendalian intern yang baik mensyaratkan fungsi pencatatan waktu hadir karyawan tidak boleh dilaksanakan oleh fungsi operasi atau oleh fungsi pembuat daftar gaji dan upah.

\section{Analisis Dokumen - Dokumen yang Digunakan dalam Sistem Informasi Akuntansi Penggajian pada CV BAHARDIAN GALON}

Dokumen -Dokumen yang digunakan dalam sistem informasi akuntansi penggajian pada CV. BAHARDIAN GALON meliputi :

\section{Daftar Hadir Karyawan}

Daftar hadir karyawan digunakan untuk mencatat kehadiran karyawan setiap hari pada saat datang sebelum memulai kerja dan pulang kerja dengan melakukan finger print (check clock). 


\section{Rekap Daftar Hadir Karyawan}

Rekap daftar hadir digunakan untuk mencatat rekap jam hadir karyawan tetap yang dihitung selama satu bulan.

\section{Daftar Gaji Karyawan}

Daftar gaji karyawan digunakan untuk mencatat jumlah gaji pokok dari masing masing karyawan, ditambah tunjangan- tunjangan dan dikurangi potongan-potongan.

\section{Slip Gaji}

Slip gaji dibuat oleh Bagian Akuntansi yang berisi rincian gaji yang diterima oleh karyawan.

\section{Bukti Transfer}

Bukti transfer digunakan sebagai bukti bahwa gaji pokok telah ditransfer ke rekening masing - masing karyawan sesuai besar gaji pokok yang ditetapkan oleh pihak manajemen.

Dokumen - dokumen untuk penggajian pada CV. BAHARDIAN GALON sudah cukup baik dan sudah sesuai dengan teori yang ada. Dokumen yang digunakan sudah cukup memadai dalam mendukung pengendalian intern gaji yang baik. Karena perusahaan memanfaatkan teknologi informasi, maka pemrosesan penggajian dibuat lebih efisien. Hal ini memberikan penghematan biaya pemrosesan gaji, mengurangi waktu dan potensi kesalahan yang diakibatkan oleh manusia. Namun masih perlu disempurnakan lagi karena tidak setiap dokumen mencantumkan pembuat dan pengesah dokumen tersebut. Terdapat kelemahan pada dokumen yang digunakan, yaitu rekap daftar hadir sebaiknya dibuat oleh bagian personalia. Tanda terima pembayaran gaji sebaiknya dibuat rangkap dua. 


\section{Analisis Catatan Akuntansi yang Digunakan dalam Sistem Informasi Akuntansi Penggajian dan}

Pengupahan pada CV. BAHARDIAN GALON Catatan akuntansi yang digunakan dalam sistem informasi akuntansi penggajian pada CV. BAHARDIAN GALON terdiri dari Jurnal Umum dan Buku Besar. Catatan akuntansi yang digunakan oleh PT. Populer Sarana Medika sudah baik dan sesuai dengan teori sebelumnya. Hal ini dibuktikan dengan dibuatnya jurnal dan buku besar untuk Merekam transaksi yang berkaitan dengan pemberian gaji karyawan.

Analisis Jaringan Prosedur yang Membentuk Sistem Informasi Akuntansi Penggajian pada CV. BAHARDIAN GALON

Prosedur pencatatan waktu hadir karyawan CV. BAHARDIAN GALON adalah sebagai berikut : Prosedur pencatatan waktu hadir karyawan CV. BAHARDIAN GALON dimulai dengan karyawan melakukan finger print (check clock) pada saat datang dan melakukan finger print (check clock) kembali pada saat pulang. Bagian Akuntansi bertugas membuat rekap daftar hadir karyawan setiap akhir bulan dan bertanggung jawab melaporkan rekap daftar hadir karyawan kepada Direktur Prosedur pembayaran gaji karyawan Pembayaran gaji pokok karyawan setiap bulan dilakukan dengan mentransfer uang gaji ke rekening masing - masing karyawan. Jaringan prosedur yang membentuk sistem informasi akuntansi penggajian pada PT. Populer Sarana Medika sudah cukup baik dan sesuai dengan teori sebelumnya. Pembayaran tunjangan karyawan dan transfer gaji pokok ke rekening masing - masing karyawan dilakukan oleh Kasir dan rekap daftar hadir karyawan dilakukan oleh bagian personalia. Prosedur pencatatan waktu hadir karyawan masih terdapat kelemahan yaitu pengawasan pengisian daftar hadir karyawan dan rekap daftar hadir karyawan masih dilakukan oleh bagian akuntansi. Pengisian daftar hadir karyawan sebaiknya diawasi oleh Bagian Personalia. Rekap daftar hadir karyawan sebaiknya juga dibuat oleh Fungsi pencatat waktu. 


\section{Analisis Efektivitas Pengendalian Intern dalam Sistem Informasi Akuntansi Penggajian pada CV. BAHARDIAN GALON}

\section{a. Struktur Organisasi}

Struktur organisasi penggajian pada CV. BAHARDIAN GALON terdiri dari bagian akuntansi yang bertanggung jawab dalam melakukan rekap daftar hadir karyawan, membuat daftar gaji karyawan, slip gaji dan Direktur yang berwenang membayarkan gaji pokok karyawan dengan mentransfer gaji ke rekening masing - masing karyawan melalui E-banking (Electronic banking ).

Efektivitas pengendalian intern sistem informasi akuntansi penggajian pada struktur organisasi CV. BAHARDIAN GALON sudah cukup baik dan sesuai dengan teori yang ada karena memiliki fungsi bagian-bagian yang belum terpisah. Hal ini ditunjukkan dengan perangkapan tugas pada bagian akuntansi yang bertindak sebagai pencatat waktu hadir sekaligus sebagai pembuat daftar gaji. Perangkapan tugas tersebut dapat mengakibatkan kecurangan dalam perhitungan gaji sehingga pemberian gaji tidak sesuai dengan kinerja karyawan. Dalam sistem pengendalian yang baik fungsi pembuat daftar gaji harus terpisah dari fungsi pencatat waktu, begitu juga dengan fungsi keuangan dan juru bayar yang harus terpisah agar tidak mengakibatkan kecurangan.

b. Sistem Otorisasi dan Pencatatan Sistem otorisasi dan pencatatan pada CV.

\section{BAHARDIAN GALON}

yaitu besarnya gaji pokok yang diterima karyawan oleh pihak manajemen. Rekap daftar hadir karyawan yang dibuat oleh Bagian Akuntansi setiap akhir bulan dilaporkan kepada Direktur.

Efektivitas pengendalian intern pada sistem otorisasi dan pencatatan pada CV. BAHARDIAN GALON sudah baik dan sesuai teori sebelumnya. Dengan adanya dokumen - dokumen dalam sistem informasi akuntansi penggajian yang digunakan sebagai bukti penting yang berkaitan dengan prosedur penggajian karyawan. Praktek yang sehat Ketelitian dan kebenaran perhitungan daftar gaji dihitung kembali kebenarannya oleh Bagian Akuntansi sebelum melakukan pembayaran gaji kepada karyawan. Pembayaran gaji pokok karyawan dilakukan dengan mentransfer uang gaji ke rekening masing - masing karyawan oleh Direktur. Slip gaji dibuat rangkap dua. 
Lembar kesatu disimpan oleh Bagian Akuntansi lembar kedua untuk diberikan kepada masing - masing karyawan. Penerapan praktek yang sehat sudah baik dan sesuai dengan teori sebelumnya. Terbukti dengan dilakukannya pengecekan kembali perhitungan gaji atau pendapatan per bulan oleh Bagian Akuntansi sebelum dibayarkan ke masing - masing karyawan karena bagian akuntansi bertanggung jawab dalam pembuatan daftar gaji per bulan karyawan. Bagian Akuntansi juga bertanggung jawab membuat slip gaji yang dibuat dua rangkap dimana lembar kesatu disimpan oleh Bagian Akuntansi dan diberikan kepada masing-masing karyawan. Pembayaran gaji pokok karyawan dilakukan dengan mentransfer uang gaji ke rekening masing-masing karyawan oleh Direktur melalui E-banking (Electronic banking).

\section{Penutup}

\section{Simpulan}

1. Fungsi-fungsi yang terkait dalam sistem informasi akuntansi penggajian pada CV. BAHARDIAN GALON kurang baik dan belum sesuai dengan teori karena pada bagian akuntansi masih merangkap sebagai pencatat waktu hadir, pembuat daftar gaji dan juga melaksanakan pembayaran gaji karyawan.

2. Dokumen-dokumenuntuk penggajian pada CV. BAHARDIAN GALON sudah cukup baik dan sudah sesuai dengan teori yang ada. Perusahaan memanfaatkan teknologi informasi sehingga pemrosesan penggajian dibuat secara komputerisasi. Namun masih perlu disempurnakan lagi karena tidak setiap dokumen mencantumkan pembuat dan pengesah dokumen tersebut.

3. Catatan akuntansi yang digunakan oleh PT. Populer Sarana Medika sudah baik dan sesuai dengan teori sebelumnya. Hal ini dibuktikan dengan dibuatnya jurnal dan buku besar untuk merekam transaksi yang berkaitan dengan pemberian gaji karyawan.

4. Jaringan prosedur yang membentuk sistem informasi akuntansi penggajian pada CV. BAHARDIAN GALON sudah cukup baik dan sesuai dengan teori sebelumnya. Tetapi prosedur pencatatan waktu hadir karyawan masih terdapat kelemahan yaitu 
pengawasan pengisian daftar hadir karyawan dan rekap daftar hadir karyawan masih dilakukan oleh bagian akuntansi.

5. Sistem Informasi Akuntansi Penggajian yang telah diterapkan oleh CV.

BAHARDIAN GALON sudah baik dan sesuai dengan teori yang ada karena telah dilengkapi Sistem Pengendalian Intern yang memadai karena memenuhi unsur- unsur Pengendalian Intern

\section{Saran}

1. Dalam sistem informasi akuntansi penggajian, sebaiknya perlu adanya pemisahan tugas dan wewenang yang jelas sehingga perangkapan fungsi dapat diminimalkan serta dapat meningkatkan pengendalian intern perusahaan. Dokumen yang digunakan dalam sistem akuntansi penggajian dan pengupahan karyawan hendaknya mendapat otorisasi dari bagian yang bertanggungjawab agar dapat mencegah adanya penyelewengan.

2. Untuk memudahkan manajemen melakukan pengawasan terhadap jalannya operasional perusahaan maka diperlukan bagian khusus yang menangani masalah pengendalian intern perusahaan, karena dalam bagian ini terdapat bagian khusus yang mengawasi bagian keuangan, personalia, serta operasional perusahaan. 


\section{Daftar Pustaka}

Ackoff, R. L. (1971). Towards a system of systems concepts. Management Science, 17(11), $661-671$

Al Fatta, H. (2007). Analisis dan Perancangan Sistem Informasi untuk keunggulan bersaing perusahaan dan organisasi modern. Penerbit Andi.

bodnar, george h., william s. hopwood. (2003). sistem informasi akuntansi (keenam). Salemba Empat.

Bodnar, george h. (2003). sistem informasi akuntansi (keenam). Salemba Empat.

Danke, Y. (2012). Analisis Perancangan Sistem Informasi Akuntansi pada Siklus Penggajian dalam rangka Efektifitas Pengendalian Internal. Jurnal Berkala Ilmiah Mahasiswa Akuntansi, 1, 20-26.

Elder, Randal J., Mark S.B., dan A. A. . (2009). Auditing and Assurance Services An Integrated Approach (A. A. Jusuf. (ed.)). Prentice Hall.

Fathansyah. (2015). Basis Data. Revisi Kedua. In Informatika, Bandung.

Hall, A. (1956). D. y FAGEN, R. E. “Definition of System”. General Systems, I, 18-29.

Hidayat, Rahayu, H. (2013). Analisis Penerapan Sistem Akuntansi Penggajian dan Pengupahan dalam Mendukung Pengendalian Intern. Jurnal Administrasi Bisnis, 6, 1-8.

Jogiyanto, H M. (2005). Analisis \& Desain Sistem Informasi. Yogjakarta: Andi Offset.

Jogiyanto, Hartono M. (1999). Pengenalan Komputer. Andi Offset, Yogyakarta.

Kadir, A. (2002). Pengenalan Sistem Informasi (Vol. Edisi 2). Yogyakarta: Andi Offset.

Mardalis. (2010). Metode Penelitian (pertama). Bumi Aksar.

McLeod Jr, R. (2001). Sistem Informasi Edisi 7 Jilid 2. Prenhallindo. Jakarta.

Mulyadi. (2001a). sistem informasi akuntansi (5th ed.). Aditya Media.

Mulyadi. (2001b). Sistem Informasi Akuntansi (5th ed.). Aditya Media. 
Mulyadi. (2001c). Sistem Informasi Akuntansi (5th ed.). Aditya Media.

Rachmad Gesah Mukti prabowo. (2015). Pengembangan sistem.

Romney, M. B., Steinbart, P. J., \& Cushing, B. E. (2000). Accounting information systems (Vol. 2). Prentice Hall Upper Saddle River, NJ.

Saraswaati, Darminto, E. (2014). Analisis Sistem Akuntansi Penggajian dan Pengupahan sebagai upaya Mendukung Tujuan.

Sutabri, T. (2012). Analisis sistem informasi. Penerbit Andi.

Sutarbi. (2005). sistem informasi managemen.

Watung, I. A., \& Sinsuw, A. A. E. (2014). PERANCANGAN SISTEM INFORMASI DATA ALUMNI FAKULTAS TEKNIK UNSRAT BERBASIS WEB. Jurnal Teknik Informatika. https://doi.org/10.35793/jti.3.1.2014.3922

Widjajanto, N. (2001). Sistem Informasi Akuntansi. Erlangga. 